\title{
Bacterial and fungal communities respond differently to varying tillage depth in agricultural soils
}

\author{
Craig Anderson ${ }^{\text {Corresp., }}{ }^{1}$, Mike Beare ${ }^{1}$, Hannah L Buckley ${ }^{2}$, Gavin Lear ${ }^{3}$ \\ 1 Plant and Food Research, Lincoln, New Zealand \\ 2 School of Science, Auckland University of Technology, Auckland, New Zealand \\ 3 School of Biological Sciences, University of Auckland, Auckland, New Zealand \\ Corresponding Author: Craig Anderson \\ Email address: Craig.Anderson@plantandfood.co.nz
}

In arable cropping systems, reduced or conservation tillage practices are linked with improved soil quality, $\mathrm{C}$ retention and higher microbial biomass, but most long-term studies rarely focus on depths greater than $15 \mathrm{~cm}$ nor allow comparison of microbial community responses to agricultural practices. We investigated microbial community structure in a long-term field trial (12-years, Lincoln, New Zealand) established in a siltloam soil over four depth ranges down to $30 \mathrm{~cm}$. Our objectives were to investigate the degree of homogenisation of soil biological and chemical properties with depth, and to determine the main drivers of microbial community response to tillage. We hypothesised that soil microbiological responses would depend on tillage depth, observed by a homogenisation of microbial community composition within the tilled zone. Tillage treatments were mouldboard plough and disc harrow, impacting soil to $\sim 20$ and $\sim 10 \mathrm{~cm}$ depth, respectively. These treatments were compared to a no-tillage treatment and two control treatments, both permanent pasture and permanent fallow. Bacterial and fungal communities collected from the site were not impacted by the spatial location of sampling across the study area but were affected by physicochemical changes associated with tillage induced soil homogenisation and plant presence. Tillage treatment effects on both species richness and composition were more evident for bacterial communities than fungal communities, and were greater at depths $<15 \mathrm{~cm}$. Homogenisation of soil and changing land management appears to redistribute both microbiota and nutrients deeper in the soil profile while consequences for soil biogeochemical functioning remain poorly understood. 
1 Title: Bacterial and fungal communities respond differently to varying tillage intensities in 2 agricultural soils

4 Craig Anderson ${ }^{\mathrm{a}^{*}}$, Mike Beare $^{\mathrm{a}}$, Hannah Buckley ${ }^{\mathrm{b}}$, Gavin Lear $^{\mathrm{c}}$

$5 \quad$ a Plant and Food Research, Gerald Street, Lincoln 7600, New Zealand

$6 \quad{ }^{\mathrm{b}}$ School of Science, Auckland University of Technology, Auckland 1142, New Zealand

7 c School of Biological Sciences, The University of Auckland, Auckland 1010, New Zealand

\section{Abstract}

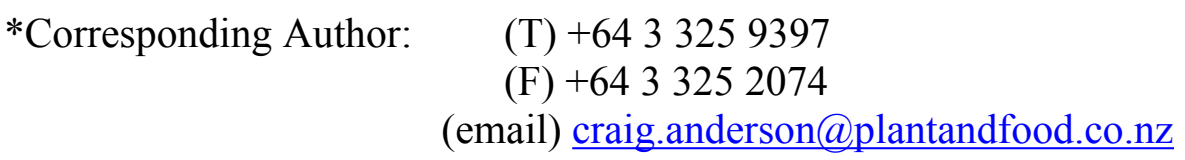

In arable cropping systems, reduced or conservation tillage practices are linked with improved soil quality, $\mathrm{C}$ retention and higher microbial biomass, but most long-term studies rarely focus on depths greater than $15 \mathrm{~cm}$ nor allow comparison of microbial community responses to agricultural practices. We investigated microbial community structure in a long-term field trial (12-years, Lincoln, New Zealand) established in a silt-loam soil over four depth ranges down to $30 \mathrm{~cm}$. Our objectives were to investigate the degree of homogenisation of soil biological and chemical properties with depth, and to determine the main drivers of microbial community response to tillage. We hypothesised that soil microbiological responses would depend on tillage depth, observed by a homogenisation of microbial community composition within the tilled zone. Tillage treatments were mouldboard plough and disc harrow, impacting soil to $\sim 20$ and $\sim 10 \mathrm{~cm}$ depth, respectively. These treatments were compared to a no-tillage treatment and two control treatments, both permanent pasture and permanent fallow. Bacterial and fungal 
26 communities collected from the site were not impacted by the spatial location of sampling across

27 the study area but were affected by physicochemical changes associated with tillage induced soil

28 homogenisation and plant presence. Tillage treatment effects on both species richness and

29 composition were more evident for bacterial communities than fungal communities, and were

30 greater at depths $<15 \mathrm{~cm}$. Homogenisation of soil and changing land management appears to

31 redistribute both microbiota and nutrients deeper in the soil profile while consequences for soil

32 biogeochemical functioning remain poorly understood.

\section{Introduction}

35 Tillage alters soil porosity, distributes carbon and nitrogen throughout the soil profile, impacts 36 microbial respiration and potentially leads to carbon loss (Singh et al. 2010). More stable 37 aggregate structure in the upper surfaces of non-tilled soils is proposed to improve soil porosity 38 and moderate evaporation, improving soil water conservation (Busari et al. 2015). While 39 increasing the abundance of water storage pores (Pagliai et al. 2004), the lower aeration of non40 tilled soils may simultaneously decrease oxygen availability, lowering aerobic turnover in the 41 soil and decreasing gaseous losses (Skiba et al. 2002). Consequently, the use of no-till soil 42 management has been promoted to land managers seeking to reduce soil carbon losses and curb 43 greenhouse gas emissions (Conant et al. 2007).

45 The impacts of soil management on microbial diversity and functioning are still under 46 investigation. Crop residues and root exudates are the main sources of soil C (Gougoulias et al. 47 2014) with tillage distributing these C-sources deeper into the soil and altering soil structure. 48 Tillage, therefore affects microbial access to fresh $\mathrm{C}$ at depth, releases previously inaccessible $\mathrm{C}$ 
49 and changes soil water and gas distribution thus affecting microbial metabolic rates. By contrast,

50 no-till management restricts microbial access to fresh $\mathrm{C}$ (by leaving residues at the surface and in

51 the vicinity of roots) and minimises soil disturbance, therefore impacting how soil-C will be

52 processed. Since soil microorganisms have primary control over C flows within the soil and

53 between the soil and atmosphere (Balaine et al. 2016), alterations of soil $\mathrm{C}$ distributions by tilling

54 are likely to impact both microbial community composition and functioning.

56 The impacts of no-till management on soil C stocks are variable compared with conventional

57 tilled systems (Helgason et al. 2014) where C stocks may be far higher (e.g., 1.7 times greater;

58 Wakindiki et al., 2017) due to surface derived plant $\mathrm{C}$ being incorporated into the soil. With this

59 in mind, it is conceivable that a moderate degree of tillage or inversion tillage may aid

60 restoration of soil $\mathrm{C}$ stocks at deeper levels in the soil profile. However, to confirm the

61 restoration of soil $\mathrm{C}$ would first require confirmation that appropriate levels of $\mathrm{C}$ exist,

62 appropriate microbial communities are present that can decompose the residues at depth and that

63 other limiting nutrients are made available. Until recently, few studies have examined the impact

64 of different tillage practices on soil microbial community structure, specifically at depths $>15 \mathrm{~cm}$

65 (Ceja-Navarro et al. 2010; Navarro-Noya et al. 2013; van Groenigen et al. 2010). Since both

66 bacterial and fungal communities play major roles in soil organic matter cycling, we examined

67 their composition within a long-term (12-year) trial to evaluate the effects of tillage down to a

68 depth of $30 \mathrm{~cm}$. For both communities, we hypothesised that there would be weaker depth-

69 related gradients in community composition in tilled soil, since tillage should homogenise the

70 soil and overshadow any depth-dependant effects. To further explore the role of tillage on depth-

71 related gradients in soil microbial community composition, we chose to compare communities 
72 in untilled soil to communities in soil tilled to depths of either 10 or $20 \mathrm{~cm}$. We also expected

73 fungal communities to be more prone to disturbance from ploughing because of their extensive

74 hyphal networks (Wardle 1995). Therefore, our objectives were to investigate the degree of

75 homogenisation of soil biological and chemical properties to depths of $30 \mathrm{~cm}$, and to identify the

76 main drivers of microbial community responses to tillage intensity.

Methods

\section{Experimental Site and Field Trial Description}

80 Replicated soil samples were taken pre-harvest (09/03/2012) from 15 plots at a long-term tillage

81 trial run by Plant \& Food Research, near Lincoln, in the South Island of New Zealand $\left(43^{\circ} 40^{\prime} \mathrm{S}\right.$

82 latitude, $172^{\circ} 28^{\prime} \mathrm{E}$ longitude; mean annual air temperature $11.4{ }^{\circ} \mathrm{C}$, mean annual rainfall 867

$83 \mathrm{~mm}$ ). The soil underlying this site is a Wakanui silt loam, classified as Udic Dystocrypt

84 according to USDA taxonomy (Soil Survey Staff 1999). Before trial establishment, the site was

85 sheep-grazed, irrigated permanent pasture that had not been cultivated for at least 14 years. Three

86 tillage methods applied in Spring and Autumn seasons were evaluated, these being; No-tillage

87 (Nn): no cultivation, seeds direct drilled; Minimum tillage (Mm): the top $10 \mathrm{~cm}$ cultivated using

88 a spring tined implement, followed by secondary cultivation (harrowing and rolling twice);

89 Intensive tillage (Ii): cultivation to $\sim 20 \mathrm{~cm}$ using a mouldboard plough, followed by secondary

90 cultivation (one pass with a spring tined implement followed by harrowing and rolling twice).

91 All tillage operations were carried out using standard commercial equipment. Spring-sown main

92 crops rotation included barley, wheat, and peas. They were followed by winter-grazed (sheep)

93 cover crops (oats or forage brassicas). All crops were sown using a Great Plains direct drill.

94 Fertiliser ( $\mathrm{N}$ and $\mathrm{P}$ ) were applied to the spring crops to ensure these nutrients were not limiting.

95 Plots representing the original ryegrass-clover pasture were maintained within the trial as a 
96 control. To balance the trial design, these plots were split into subplots; permanent pasture (Pp),

97 and permanent fallow (Pf). The Pp sub-plots were grazed with sheep (typically 10 times per year;

9820 sheep per plot). The main fertiliser applied to the Pp plot was superphosphate. The Pf subplots

99 received no fertiliser and had no animal or vehicle trafficking throughout the trial. Herbicide

100 (Glyphosate) was used to maintain the Pf subplots plant free. Management (irrigation, fertiliser,

101 grazing regime) of the Pp plots remained the same as before the trial. All treatments (i.e. Arable

102 crops, $\mathrm{Pp}$ and $\mathrm{Pf}$ ) were irrigated in summer to ensure that water was not limiting to pasture or

103 crop growth. Treatment plots were replicated three times in an incomplete Latin square (i.e. five

104 treatments $\mathrm{x}$ three replicate plots $=15$ plots; see Fig. 1). The size of individual plots was $28 \mathrm{~m} \mathrm{x}$

$1059 \mathrm{~m}$. Further trial details can be obtained from Fraser et al. (2013). The long term field trial was

106 operated by Plant and Food Research. No additional permits were required for sample collection.

108

Two types of soil samples were taken from each plot: (1) six surface $25 \mathrm{~mm}$ diameter

110 core samples $(0-7.5 \mathrm{~cm})$ where each sample was analysed separately to confirm the impact of

111 spatial heterogeneity on sample data and (2) eight deeper $5 \mathrm{~cm}$ diameter core samples separated

112 into four depth ranges $(0-7.5 \mathrm{~cm}, 7.5-15 \mathrm{~cm}, 15-25 \mathrm{~cm}$ and $25-30 \mathrm{~cm})$, which were later

113 composited by depth (Fig. 1). Soil used for chemical and physical analysis was stored at $4{ }^{\circ} \mathrm{C}$

114 prior to use and $2 \mathrm{~g}$ aliquots of each sample frozen in Eppendorf tubes for DNA extraction. Soil

115 subsamples were taken from each depth to measure: (1) water content, (2) pH, (3) bulk

116 density/mean weight diameter (MWD), (4) exchangeable acidity, (5) exchangeable aluminium,

117 (6) concentrations of $\mathrm{C}$ and $\mathrm{N}$, and (7) microbial biomass $\mathrm{C}$ and $\mathrm{N}$. 


\section{Soil chemical analysis}

120 Gravimetric soil moisture content was determined by the mass difference before and after drying

121 at $105^{\circ} \mathrm{C}$ for $16 \mathrm{~h}$. The $\mathrm{pH}$ of each sample was determined using a glass electrode at 1:2 field

122 moist sample to water ratio (Hendershot et al. 2008). Bulk density $(<4 \mathrm{~mm}$ ) was calculated from

123 the weight of field-moist soil of known volume, corrected for its stone and moisture contents.

124 Aggregate stability or mean weight diameter (MWD) was determined by first separating 2-4 mm

125 aggregates from whole soil by sieving, and then air-drying them at $25^{\circ} \mathrm{C}$ before aggregate

126 stability determination using a wet-sieving method (Kemper \& Rosenau 1986). The air-dried 2-4

$127 \mathrm{~mm}$ aggregates $(50 \mathrm{~g})$ were sieved underwater for 20 minutes on a nest of sieves $(2.0,1.0$ and 0.5

$128 \mathrm{~mm}$ diameter). The soil remaining on each sieve was weighed after oven drying at $105^{\circ} \mathrm{C}$. The

129 aggregate stability was expressed as a mean weight diameter (MWD):

130

$$
M W D=\sum_{i=1}^{n} x_{i} w_{i}
$$

131 where $x_{i}$ is the mean diameter of adjacent sieves and $w_{i}$ is the proportion of the total sample

132 retained on a sieve.

133 Exchangeable acidity (Exch. Acid.) and aluminium (Exch. Al.) was determined by extraction

134 using $1 \mathrm{M} \mathrm{KCl}$. The amount of $\mathrm{H}^{+}$and $\mathrm{Al}^{3+}$ in the extracts was determined by titration as

135 described by Sims (1996). Total carbon (C) and nitrogen (N) contents were determined by the

136 Dumas dry combustion method at $950^{\circ} \mathrm{C}$ using a Truspec $\mathrm{C} / \mathrm{N}$ analyzer (LECO, St. Joseph, 137 Michigan, USA). 
139 Microbial biomass $\mathrm{C}(\mathrm{MBC})$ and $\mathrm{N}(\mathrm{MBN})$ were determined by chloroform fumigation-

140 extraction as described by Sparling \& West (1988). Pre- and post-fumigation extracts were

141 analysed for organic $\mathrm{C}$ by combustion catalytic oxidation using a TOC-V $\mathrm{V}_{\mathrm{CSH}}$ analyzer (Shimadzu

142 Corporation, Kyoto, Japan) and for organic $\mathrm{N}$ by the persulfate oxidation method described by

143 Cabrera \& Beare (1993). Physicochemical data collected from the site are provided in

144 Supplementary File 1.

145

\section{Production and manipulation of ARISA data from extracted DNA}

147 Automated Ribosomal Intergenic Spacer Analysis (ARISA)

148

149 For each sample (160 in total), DNA was extracted from $0.25 \mathrm{~g}$ freeze-dried soil using

150 Powersoil ${ }^{\circledR}$-htp 96 well DNA isolation kits (MoBio Laboratories Inc., Carlsbad, CA., USA)

151 following the manufacturer's instructions. Automated Ribosomal Integenic Spacer Analysis

152 (ARISA) was then used to evaluate the composition of bacterial and fungal communities in each

153 sample according the method of Lear et al. (2008). This PCR-based method characterises the

154 structure of the microbial community within each sample by recording the length (in base pairs,

155 b.p.) of the intergenic spacer (ITS) regions of the constituent microbes, i.e., between the bacterial

156 16S rRNA and 23S rRNA genes or the fungal 18S rRNA and large ribosomal subunit genes.

157

158 PCR amplification of bacterial ITS regions was undertaken on the extracted DNA using Promega

159 GoTaq ${ }^{\circledR}$ Green DNA polymerase master mix (Invitro Technologies Ltd., Auckland, New

160 Zealand) and the primers SDBact (5'-TGC GGC TGG ATC CCC TCC TT-3') and LDBact (5'-

161 CCG GGT TTC CCC ATT CGG) (Ranjard et al. 2001), with the following amplification

162 conditions: (i) $95{ }^{\circ} \mathrm{C}$ for $5 \mathrm{~min}$; (ii) 30 cycles of $95{ }^{\circ} \mathrm{C}$ for $30 \mathrm{~s}, 61.5{ }^{\circ} \mathrm{C}$ for $30 \mathrm{~s}, 72{ }^{\circ} \mathrm{C}$ for $90 \mathrm{~s}$ 
163 and then (iii) $72{ }^{\circ} \mathrm{C}$ for $10 \mathrm{~min}$. The primer SDBact was labelled at the 5 '-end with HEX (6-

164 carboxyhexafluorescein) fluorochrome (Invitrogen Molecular Probes, New Zealand) to enable 165 analysis by ARISA.

167 For the fungi, the PCR primers used were FunNS1 (5'-GAT TGA ATG GCT TAG TGA 168 GG -3') (Martin \& Rygiewicz 2005) and 3126T (5'- ATA TGC TTA AGT TCA GCG GGT -3')

169 (Ranjard et al. 2001). PCR amplification used the Phusion ${ }^{\circledR}$ polymerase (NEB, Ipswich, MA, 170 USA) according to the manufacturer's instructions, with the following amplification conditions:

171 (i) $98^{\circ} \mathrm{C}$ for $2 \mathrm{~min}$; (ii) 35 cycles of $98^{\circ} \mathrm{C}$ for $10 \mathrm{~s}, 55^{\circ} \mathrm{C}$ for $30 \mathrm{~s}, 72^{\circ} \mathrm{C}$ for $45 \mathrm{~s}$ and then (iii) 72

$172{ }^{\circ} \mathrm{C}$ for $20 \mathrm{~min}$. The primer FunNS1 was labelled at the 5'-end with FAM (6-carboxyfluorescein)

173 fluorochrome (IDT, Asia Pacific, Singapore).

174

175 Products were each purified (Zymo DNA clean and Concentrator kit; Ngaio Diagnostics 176 Ltd., Nelson, New Zealand) and DNA concentration (ng $\mu \mathrm{l}^{-1}$ ) individually determined using a 177 Nanodrop ND-100 spectrophotometer (NanoDrop Technologies, Rockland, DE). Appropriate 178 volumes of cleaned PCR product (diluted with ultrapure $\mathrm{H}_{2} \mathrm{O}$ if necessary) providing a final 179 DNA mass of 5 to $10 \mathrm{ng}$ were then transferred to a 96-well sequencing plate and dried in a 180 speedvac for $2 \mathrm{~h}$ at $60^{\circ} \mathrm{C}$. The dry sample was resuspended in $15 \mu \mathrm{Hi}$-Di deionised formamide 181 and Genescan LIZ-1200 internal size standard (ABI Ltd.). The sample was heated (5 min, $\left.95^{\circ} \mathrm{C}\right)$ 182 and analysis was carried out on an ABI 3130XL genetic analyser with POP7 chemistry and a 36 $183 \mathrm{~cm}$ array (ABI Ltd.).

184

185 Quantitative Analysis of ARISA Data 
186 GENEMAPPER software (v. 3.7; ABI Ltd) was used to assign a fragment length (in nucleotide

187 base pairs) to ARISA peaks, via comparison with the standard ladder (LIZ1200; ABI Ltd.). To

188 include the maximum number of peaks whilst excluding background fluorescence, only peaks

189 with a fluorescence value of $50 \mathrm{U}$ or greater were analysed. As the $16 \mathrm{~S}-23 \mathrm{~S}$ region is thought to

190 range between $\sim 140$ and 1530 bp (Fisher \& Triplett 1999), fragments $<150$ bp were excluded

191 from analysis. No samples contained fragments $>1000 \mathrm{bp}$. The same size (bp) parameters were

192 used for the fungi as these samples also did not contain any fragments $>1000 \mathrm{bp}$. The total area

193 under the curve was normalised (to 100) to remove differences in profiles caused by different

194 initial DNA template quantities, and peak size was rounded to the nearest whole number. Each

195 ARISA sample therefore consisted of 851 operational taxonomic groupings of bacteria or fungi,

196 which represent the length of the intergenic spacer region of constituent microbes (in bp),

197 thereby providing an informative profile of the bacterial and fungal community composition

198 within each sample. OTU tables are available provided in Supplemental Files S2-S3.

200 To visualise multivariate patterns in the soil microbial community structure among samples,

201 nonmetric multidimensional scaling (nMDS) was done using the Bray Curtis measure. Rather

202 than using multivariate analysis of variance MANOVA to test the data, which assumes normal

203 distributions, and implicitly Euclidean distances, we chose to use permutational MANOVA (or

204 PERMANOVA; Anderson, 2011) with the data assigned to the factors Treatment (Pf, Pf, Ii, Nn

205 and $\mathrm{Mm})$ and Depth $(0.7 .5,7.5-15,15-25$ and 35-30 $\mathrm{cm})$. MVDISP was used to compare the

206 extent of multivariate data dispersion across these groups. These multivariate analyses were

207 performed using the PRIMER v.6 computer program (Clarke \& Gorley 2006) with the additional

208 add-on package PERMANOVA+ (Anderson et al. 2008). 
210 We used the aov function in R version 2.14 (R Core Team 2012) to perform analyses of variance

211 on soil chemical data using a two-way layout (treatment; depth), with interaction terms.

212 Canonical redundancy analysis (RDA) and was used to summarise variation in the bacterial and

213 fungal community data that could be explained by our set of explanatory variables (e.g., $\mathrm{pH}$, soil

214 water content). Variance partitioning was then performed using the function varpart.MEM in R,

215 following Borcard et al. (2011) to describe and partition variation in community composition

216 between two sets of explanatory variables: soil chemical properties and geographic location.

217

218 Results and Discussion

219 Analysis of the surface soil samples $(0-7.5 \mathrm{~cm})$ showed significant variation in 220 microbial community composition among treatments (Fig. 2, PERMANOVA all $P<0.001$ ).

221 Bacterial and fungal composition from the five treatments differed significantly irrespective of 222 whether the data remained untransformed or was $\log (\mathrm{X}+1)$ transformed to remove computational 223 bias derived from dominant OTUs (operational taxonomic units - broadly representing 224 'unknown' phyla). These results confirm soil management practices impact the composition of 225 both bacterial and fungal communities, supporting the findings of other recent studies (Busari et al. 2015; Ceja-Navarro et al. 2010; Mathew et al. 2012).

227

The treatment differences among the bacterial community data were more pronounced 229 than those of the fungal data, as the former formed more distinct clusters on an nMDS plot (Fig. 2). The removal of the $\mathrm{Pp}$ and $\mathrm{Pf}$ data from the analysis further improved the separation of the 231 cropped tillage treatments and reduced the 2D-Stress goodness of fit statistic to 0.16 and 0.15 for 
232 bacteria and fungi respectively, improving the certainty of the visual nMDS solution (Cox \& Cox

233 1992). All pairwise PERMANOVA comparisons among treatments were significant for bacteria,

234 but only three (Pp-Ii, Pf-Nn, and Mm-Pf) were significant for fungi (i.e., PERMANOVA $P$ all $<$

235 0.001) suggesting that bacterial communities in the surface soil $(0-7.5 \mathrm{~cm})$ were more sensitive

236 to tillage treatment than fungal communities. This tillage treatment effect may be because

237 bacteria tend to dominate in soils that are intensively managed, where they drive decomposition

238 and nutrient cycles (Garcia-Orenes et al. 2013). The greatest pairwise Bray-Curtis distances

239 between data representing any two treatments for both taxa were between the various no-till

240 treatments, i.e., between $\mathrm{Pf}$ and $\mathrm{Pp}$ for bacteria and between $\mathrm{Pf}$ and $\mathrm{Nn}$ for fungi. Since greater

241 average Bray-Curtis distances among data indicate greater differences in overall community

242 composition, these findings confirm that tillage as a disturbance drives microbial community

243 composition to a lesser degree than other management effects, such as the presence of permanent

244 pasture, grazing or vegetation removal. We suggest tillage treatment differences have less effect

245 because for both bacterial and fungal communities, average community similarity (i.e., average

246 Bray-Curtis distances were least) comparing the treatments $\mathrm{Mm}$ and $\mathrm{Nn}$. For samples taken

247 across depths, two-way ANOVA showed that all soil chemical properties, except concentrations

248 of exchangeable aluminium and acidity, differed significantly by treatment depth (Table 1 and

249 Supplementary Figure S1). With the exception of soil water content, the greatest difference

250 among treatments was again between the non-till control treatments Pp and Pf, and the biggest

251 difference among depths was between $0-7.5 \mathrm{~cm}$ and $15-25 \mathrm{~cm}$, noting that chemical data was

252 never obtained from the deepest $(25-30 \mathrm{~cm})$ samples. Previous research at this field site has

253 indicated that crop productivity is not influenced by tillage, neither is nutrient input (pers.

254 comm., Denis Curtin, 2017). However, tillage introduced a degree of homogenisation that was 
255 reflected in the depth profiles of soil chemical properties and nutrient distribution. Soil chemical

256 attributes varied little with depth under intensive tillage, which is of relevance since variation in

257 nutrient inputs and soil depth are suggested to be important drivers of microbial community

258 change (Jangid et al. 2008; Jeffery et al. 2007).

NMDS and PERMANOVA showed that bacterial community composition, like soil 261 chemical properties, varied predictably with depth and tillage treatment. Treatment effects were greatest among the shallowest soil samples $(\leq 15 \mathrm{~cm})$ compared with deeper soil, with these data points being separated further apart on the nMDS plot as compared to samples collected at greater depth (Fig. 3a). Multivariate dispersion index values (i.e. mean Bray Curtis dissimilarities among samples within groups) confirmed greater variation in bacterial community composition comparing samples collected at shallower depth (MVDISP $=1.3,1.2,0.8$ and 0.8 for samples collected from $0-7.5,7.5-15,15-25$ and $25-30 \mathrm{~cm}$, respectively, where greater values indicate greater multivariate data dispersion within the group). Overall, PERMANOVA only showed significant pairwise treatment effects to a depth of $25 \mathrm{~cm}$. These results are consistent with our hypothesis that the tillage effects on microbial communities would decline or weaken with depth.

Fungal community composition changed with increasing sample depth but unlike the bacterial community data, no consistent pattern is observable aside from some separation between sample data from tillage treatments that were cropped versus non-cropped Pp and Pf 275 treatments (Fig. 3b). MVDISP calculations showed that the multivariate dispersion of samples was lowest for those taken at $0-7.5$ or $25-30 \mathrm{~cm}$ and therefore the fungal communities did not show the same patterns of decreasing variation among treatments with depth (MVDISP $=0.8$, 
278 1.1, 1.5 and 0.7 for samples collected from $0-7.5,7.5-15,15-25$ and $25-30 \mathrm{~cm}$, respectively). A

279 number of reasons can be proposed to explain this finding. First, since most soil-dwelling fungi

280 are aerobic (Gruninger et al. 2014) is it commonly observed that they form weak depth related

281 gradients in composition compared to bacteria, which have a far greater diversity of metabolic

282 traits related to respiration (Richardson 2000). Additionally, being larger organisms, the biomass

283 of single multicellular fungi is likely to be represented at multiple soil depths (Genney et al.

284 2006), thereby exhibiting weaker depth-related gradients in composition across small spatial

285 scales. However, it remains possible that the apparent difference in bacterial and fungal

286 community treatment responses is also impacted by the choice of DNA fragments amplified,

287 which can influence both the number and composition of OTUs detected in a community (Kumar

288 et al. 2011). To address this issue, it may be desirable in future studies to assess variation in both

289 bacterial and fungal community composition using a range of genetic markers, analysed by either

290 DNA fingerprinting (Adair et al. 2013) or sequencing methods (Hermans et al. 2017).

291

292

Canonical redundancy analysis (RDA) was used to describe and partition variation in

293 community composition between two sets of explanatory variables: soil chemical properties and

294 geographic location. Soil chemical properties alone explained $25 \%$ and $22 \%$ of the variation in

295 bacterial and fungal community composition, respectively; whereas, spatial location could

296 explain only $2 \%$ or $3 \%$ of the variation in bacterial or fungal composition, respectively. This

297 confirms that within this field trial microbial communities are responding more to soil chemical

298 properties rather than to spatial location in the field or plot. 
301 OTUs) in the $0-7.5 \mathrm{~cm}$ depth was greater than at lower depths (Fig. $4 ; P<0.001$ ), but did not

302 differ among treatments. In contrast, fungal richness did not significantly differ by depth or

303 treatment perhaps also explaining why variance partitioning showed that soil chemical properties

304 explained $31 \%$ of the bacterial richness but only $5 \%$ of the variation in fungal richness. Depth $\times$

305 treatment interactions were not significant for the OTU richness of either taxon. The general lack

306 of effect of either sample depth or treatment on microbial community richness was not

307 unexpected, however. DNA fingerprinting methods do not provide species level diversity

308 estimates and are not suitable to report absolute measures of community richness (Fierer 2007).

309 Additionally, the metabolic complexity of microbial life means that high levels of diversity are

310 commonly observed even in environments that are commonly perceived as being extreme for

311 life, such as high temperature, highly acidic and polluted environments (Du et al. 2009; Savage

312 et al. 2016), or in deep sediments for example (Lehman et al. 2001).

314 Overall, our study confirms tillage has significant impacts for both the biology and

315 chemistry of soil. Previous studies examining soil carbon and nitrogen concentrations have

316 suggested no significant difference, or even lower soil carbon concentrations under reduced

317 tillage systems (Powleson et al. 2014). However, tillage practices have the potential to impact

318 not only total carbon and nitrogen stocks, but their distribution in the soil. Here, as observed by

319 others (Du et al. 2009; Zhao et al. 2015), we confirm concentrations of soil and microbial

320 biomass carbon and nitrogen were reduced in the surface soil by tillage, whereas they were

321 greater at depth, indicating the transfer of biomass to lower soil layers by mechanical tillage.

322 Although the ARISA methodology lacks in-depth precision below perhaps order level (Gobet et 
323 al. 2014), the method was sufficient to indicate that bacterial community composition is more

324 responsive to tillage treatment differences than fungi. Tillage affected the composition, but not

325 the richness, of soil microbial communities. Changes in community composition with depth

326 appeared to be related to tillage intensity with the deeper mouldboard plough $(0-20 \mathrm{~cm})$ acting to

327 homogenise soil nutrients and microbial communities throughout the soil depth affected by this

328 disturbance. Moderate tillage with disc harrow $(0-10 \mathrm{~cm})$ and the no-till treatments behaved

329 similarly to each other, exhibiting a higher degree of community variation with depth. We

330 confirm the significant impact of tillage on soil microbial community composition, perhaps

331 resulting from the homogenisation of local soil chemical characteristics. Soil microorganisms are

332 known to impact agricultural production, for example by controlling nutrient availability and by

333 mediation of plant stress tolerance (de Souza et al. 2015; Ferrara et al. 2012; Zahran 1999).

334 Further studies, perhaps also investigating plant biomass yield and quality, are now required to

335 confirm the impact of tillage related changes in soil microbial community composition for plant

336 health and production potential.

\section{References}

Adair K, Wratten S, D., and Lear G. 2013. Soil phosphorous depletion and shifts in plant communties change bacterial community structure in a long-term grassland managemnt trial. Environmental Microbiology Reports 5:404-413.

Anderson MJ. 2001. A new method for non-parametric multivariate analysis of varience. Austral Ecology 26:32-46.

Anderson MJ, Gorley RN, and Clarke KR. 2008. PERMANOVA+ for PRIMER: guide to software and statistical methods. PRIMER-E Ltd., Plymouth, United Kingdom.

Balaine N, Clough TJ, Beare MH, Thomas SM, and Meenken ED. 2016. Soil gas diffusivity controls $\mathrm{N}_{2} \mathrm{O}$ and $\mathrm{N}_{2}$ emissions and their ratio. Soil Science Society of America Journal 80:529-540.

Borcard D, Gillert F, and Legendre P. 2011. Numerical Ecology with R. New York: Springer. 
352

353

354

355

356

357

358

359

360

361

362

363

364

365

366

367

368

369

370

371

372

373

374

375

376

377

378

379

380

381

382

383

384

385

386

387

388

389

390

391

392

393

394

395

396

Busari MA, Kukal SS, Kaur A, Bhatt R, and Dulazi AA. 2015. Conservation tillage impacts in soil, crop and the environment. International Soil and Water Conservation Research 3:119-129.

Cabrera ML, and Beare MH. 1993. Alkaline persulfate oxidation for determining total nitrogen in microbal biomass extracts. Soil Science Society of America Journal 57:1007-1012.

Ceja-Navarro JA, Rivera-Orduna FN, Patino-Zuniga L, Vila-Sanjurjo A, Crossa J, Govaerts B, and Dendooven L. 2010. Phylogenetic and multivariate analyses to determine the effects of different tillage and residue management practices on soil bacterial communities. Applied and Environmental Microbiology 76:3685-3691.

Clarke KR, and Gorley RN. 2006. PRIMER v6:User Manual/Tutorial. PRIMER_E, Plymouth, UK.

Conant RT, Easter M, Paustian K, Swan A, and Williams S. 2007. Impacts of periodic tillage on soil C stocks: A synthesis. Soil and Tillage Research 95:1-10.

Cox MAA, and Cox TF. 1992. Interpretation of stress in nonmetric multidimensional scaling. Statistica Applicata 44:611-628.

de Souza R, A. A, and Passaglia LMP. 2015. Plant growth-promoting bacteria as inoculants in agricultural soils. Genetics and Molecular Biology 38:1415-1457.

Du Z, Ren T, and Hu C. 2009. Tillage and residue removal effects on soil and nitreogen storage in the North China Plain. Soil Science Society of America Journal 74:196-202.

Ferrara FIS, Oliveira ZM, Gonzales HHS, Floh EIS, and Barbosa HR. 2012. Endophytic and rhizospheric enterobacteria isolated from sugar cane have differnt potentials for producing plant growth-promoting substances. Plant and Soil 353:409-417.

Fierer N. 2007. Tilting at windmills: a response to a recent critique of terminal restriction fragment length polymorphism data. Applied and Environmental Microbiology 73:80418042.

Fisher MM, and Triplett EW. 1999. Automated approach for ribosomal intergenic spacer analysis of microbial diversity of microbial diversity and its applications to freshwater bacterial communities. Applied and Environmental Microbiology 65:4630-4636.

Fraser PM, Curtin D, Harrison-Kirk T, Meenken ED, Beare MH, Tabley F, Gillespie RN, and Francis GS. 2013. Winter nitrate leaching under different tillage and winter cover crop management practices. Soil Science Society of America Journal 77.

Garcia-Orenes F, Morugan-Coronado A, Zornoza R, and Scow K. 2013. Changes in soil microbial community structure infleunced by agricultural management practices in a Mediterranean agro-ecosystem. PLoS ONE 8:e80522.

Genney DR, Anderson IC, and Alexander IJ. 2006. Fine-scale distribution of pine ectomycorrhizas and their extramatrical mycelium. New Phytologist 170:381-390.

Gobet A, Boetius A, and Ramette A. 2014. Ecological coherence of diversity patterns derived from classical fingerprinting and Next Generation Sequencing techniques. Environmental Microbiology 16:2672-2681.

Gougoulias C, Clark JM, and Shaw LJ. 2014. The role of soil microbes in the global carbon cycle: tracking the below-ground microbial processing of plant-derived carbon for manipulating carbon dynamics in agricultural systems. Journal of the Science of Food and Agriculture 94:2362-2371.

Gruninger RJ, Puniya AK, Callaghan TM, Edwards JE, Youssef N, Dagar SS, Fliegerova K, Griffith GW, Forster R, Tsang A, McAllister T, and Elshahed MS. 2014. Anaerobic fungi 
(phylum Neocallimastigomycota): advances in understanding their taxonomy, life cycle, ecology, role and biotechnological potential. FEMS Microbiology Ecology 90:1-17.

Helgason BL, Gregorich EG, Janzen HH, Ellert BH, Lorenz N, and Dick RP. 2014. Long-term microbial retention of residue $\mathrm{C}$ is site-specific and depends on residue placement. Soil Biology \& Biochemistry 68:231-240. 10.1016/j.soilbio.2013.10.002

Hendershot WH, Lalande H, and duquette M. 2008. Soil reaction and exchangeable activity. In: Carter MR, and Gregorich EG, eds. Soil Sampling Methods and Analysis. Boca Raton, FL, USA: CRC Press, 173.

Hermans SM, Buckley HL, Case BS, Curran-Cournane F, Taylor M, and Lear G. 2017. Bacteria as emerging indicators of soil condition. Applied and Environmental Microbiology 83:e02826-02816.

Jangid K, Williams MA, Franzluebbers AJ, Sanderlin JS, Reeves JH, Jenkins MB, Endale DM, Coleman DC, and Whitman WB. 2008. Relative impacts of land-use, management intensity and fertilization upon soil microbial community structure in agricultural systems. Soil Biology \& Biochemistry 40:2843-2853. 10.1016/j.soilbio.2008.07.030

Jeffery S, Harris JA, Rickson RJ, and Ritz K. 2007. Microbial community phenotypic profiles change markedly with depth within the first centimetre of the arable soil surface. Soil Biology \& Biochemistry 39:1226-1229.

Kemper WD, and Rosenau RC. 1986. Aggregate stabilty and size distribution. In: Klute A, ed. Methods of Soil Analysis, Part 2 Chemical and Mineralogical Methods, 2nd Edition. Madison, WI: Soil Science Society of America, 491-515.

Kumar PS, Brooker MR, Dowd SE, and Camerlengo T. 2011. Target region selection is a critical determinant of community fingerprints generated by $16 \mathrm{~S}$ pyrosequencing. PLoS ONE 6:e20956.

Lear G, Anderson MJ, Smith JP, Boxen K, and Lewis GD. 2008. Spatial and temporal heterogeneity of the bacterial communties in stream epilithic biofilms. FEMS Microbiology Ecology 65:463-473.

Lehman RM, Roberto FF, Earley D, Bruhn DF, Brink SE, O’Connell SP, Delwiche ME, and Colwell FS. 2001. Attached and unattached bacterial communities in a 120-meter corehole in an acidic, crystaline rock aquifer. Applied and Environmental Microbiology 67:2095-2106.

Martin KJ, and Rygiewicz PT. 2005. Fungal-specific PCR primers developed for analysis of the ITS region of environmental DNA extracts. BMC Microbiology 5:28.

Mathew RP, Feng Y, Githinji L, Ankumah R, and Balkcom KS. 2012. Impact of no-tillage and conventional tillage systems on soil microbial communities. Applied and Environmental Soil Science article ID 548620.

Navarro-Noya YE, Gomez-Acata S, Montoya-Ciriaco N, Rojas-Valdez A, Suarez-Arriaga MC, Valenzuela-Encinas C, Jimenez-Bueno N, Verhulst N, Govaerts B, and Dendooven L. 2013. Relative impacts of tillage, residue management and crop-rotation on soil bacterial communities in a semi-arid agroecosytem. Soil Biology \& Biochemistry 65:86-95.

Pagliai M, Vignozzi N, and Pellegrini S. 2004. Soil structure and the effect of management practices. Soil and Tillage Research 79:131-143.

Powleson DS, Stirling CM, Jat ML, Gerard BG, Palm CA, Sanchez PA, and Cassman KG. 2014. Limited potential of no-till agriculture for climate change mitigation. Nature Climate Change 4:678-683. 
442 R Core Team. 2012. R: A language and environment for statistical computing. R foundation for

443

444

445

446

447

448

449

450

451

452

453

454

455

456

457

458

459

460

461

462

463

464

465

466

467

468

469

470

471

472

473

474

475

476

477

478 statistical computing, Vienna, Austria. http://www.r-project.org/.

Ranjard L, Poly F, Lata JC, Mougal C, Thioulouse J, and Nazaret S. 2001. Characterization of bacterial and fungal soil communities by automated ribosomal intergenic spacer analysis fingerprints: biological and methodological variability. Applied and Environmental Microbiology 67:4479-4487.

Richardson DJ. 2000. Bacterial respiration: a flexible process for a changing environment. Microbiology 146:511-571.

Savage AM, Hills J, Driscoll K, Fergus DJ, Grunden AM, and Dunn RR. 2016. Microbial diversity of extreme habitats in human homes. PeerJ 4:e2376.

Sims JT. 1996. Lime Requirement. In: Sparks DL, ed. Methods of Soil Analysis Part 2: Chemical Properties (3rd Ed). Madison, WI: Soil Science Society of Americal Journal, 491-515.

Singh BK, Bardgett RD, Smith P, and Reay DS. 2010. Microorganisms and climate change: terrestrial feedbacks and mitigation options. Nature Reviews Microbiology 8:779-790.

Skiba U, van Dijk S, and Ball BC. 2002. The influence of tillage on $\mathrm{NO}$ and $\mathrm{N}_{2} \mathrm{O}$ fluxes under spring and winter barley. Soil Use and Management 18:340-345.

Soil Survey Staff. 1999. Soil taxonomy: A basic system of soil classification for making and interpreting soil surveys. 2nd edition. National Resources Conservation Service. U.S. Department of Agriculture Handbook 436.

Sparling GP, and West AW. 1988. A direct extraction method to estimate soil microbial C: calibration in situ using microbial respiration and 14-C labelled cells. Soil Biology \& Biochemistry 20:337-343.

van Groenigen K-J, Bloem J, Baath E, Boeckx P, Rousk J, Bode S, Forristal D, and Jones MB. 2010. Abundance, production and stabilization of microbial biomass under conventional and reduced tillage. Soil Biology and Biochemistry 42:48-55.

Wakindiki IIC, and Njeru SK. 2017. Organic carbon associated with tillage-induced aggregates of soil quartz-dominated dominated loamy soils in a semi-arid region of South Africa. South African Journal of Plant and Soil 34:239-242.

Wardle DA. 1995. Impacts of disturbance on detritus food webs in agro-ecosystems of contrasting tillage and weed management practices. Advances in Ecological Research 26:105-185.

Zahran HH. 1999. Rhizobium-legume sybmiosis and nitrogen fixation under severe conditions and in an arid climate. Microbiology and Molecular Reviews 63:968-989.

Zhao X, Xue J-F, Zhang X-Q, Kong F-L, Chen F, Lal R, and Zhang J-L. 2015. Stratification and storage of soil organic carbon and nitrogen as affected by tillage practices in the North China Plain. PLoS ONE 10:0128873. 


\section{Figure 1 (on next page)}

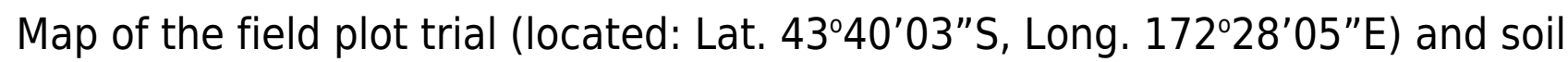
sampling strategy.

(A) Map of study site. Tillage treatments are (Pp) permanent pasture, (Pf) permanent fallow, (li) intensive tillage to $20 \mathrm{~cm}$, (Mm) minimum tillage to $10 \mathrm{~cm}$ and (Nn) no-till. Plots labelled () represent a variety of treatments not investigated in the present study. All 15 plots (5 treatments $\times 3$ replicates) were sampled twice on the same day. (B) During the first sampling event six samples were collected from each plot from a depth of $0-7.5 \mathrm{~cm}$ to provide a total of 90 samples. (C) During the second sampling event, eight sample cores were collected from each plot and cores separated into depths of $0-7.5 \mathrm{~cm}, 7.5-15 \mathrm{~cm}, 150-25 \mathrm{~cm}$ and $25-30 \mathrm{~cm}$, before the soil from each depth was composited, providing an additional 60 samples for analysis. 

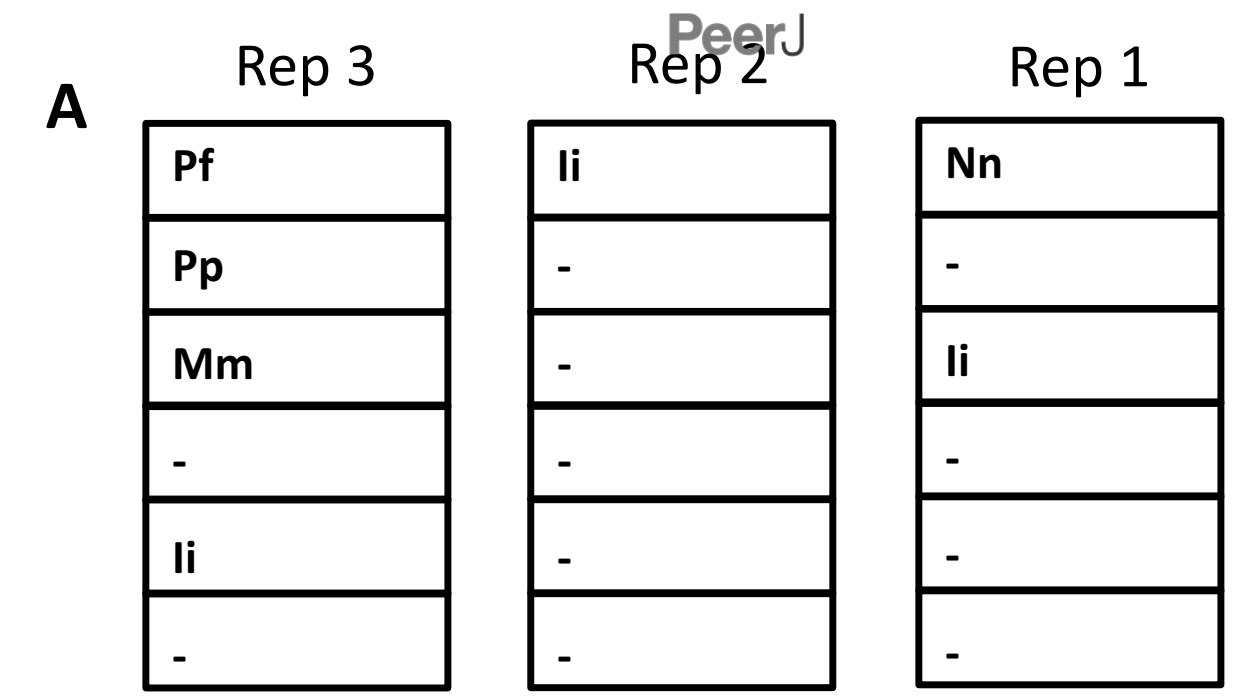

$25 \mathrm{~m} \uparrow$
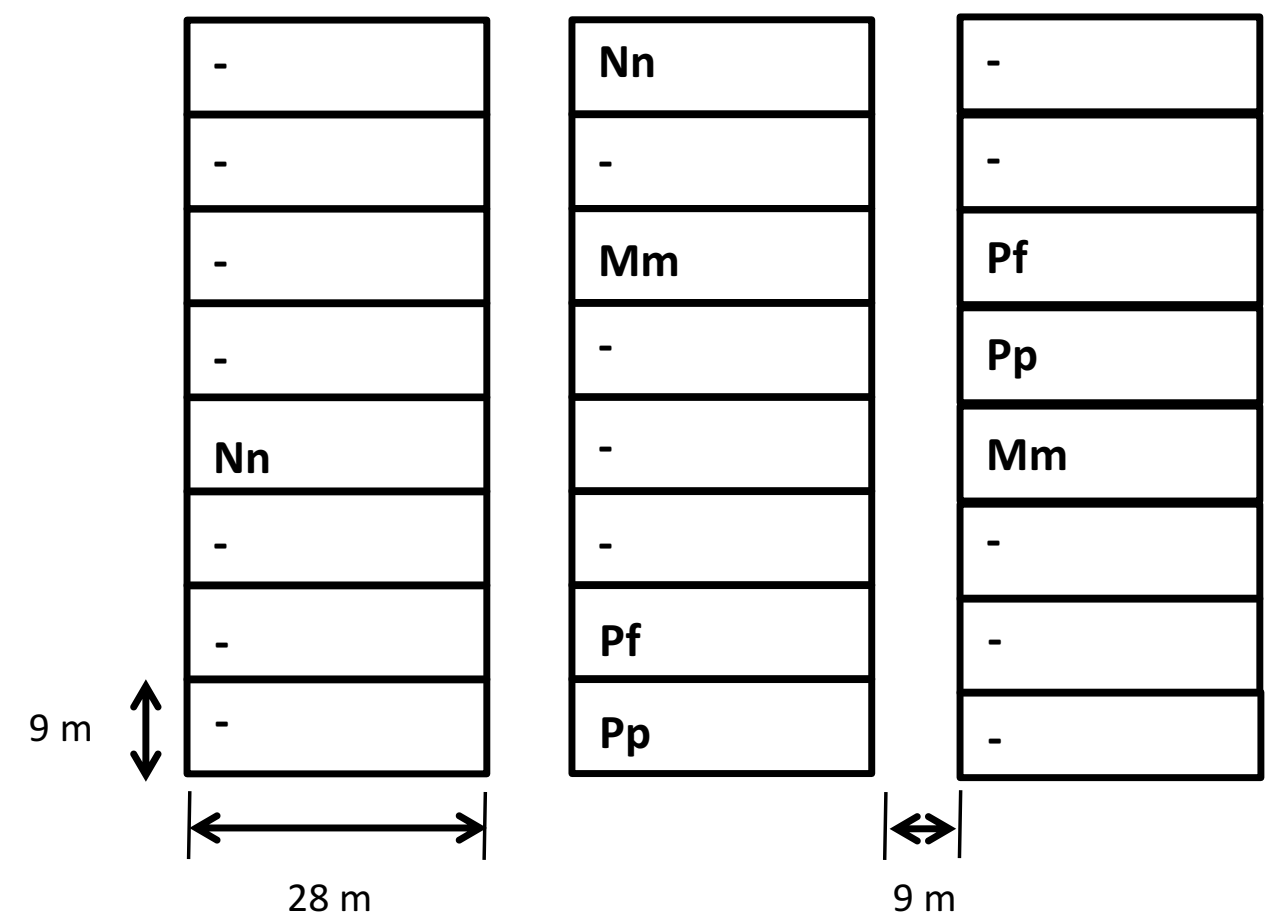

Manuscript to be reviewed

B

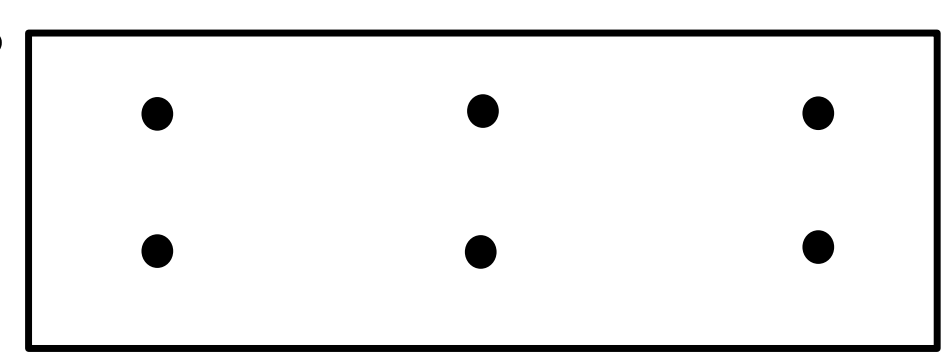

c

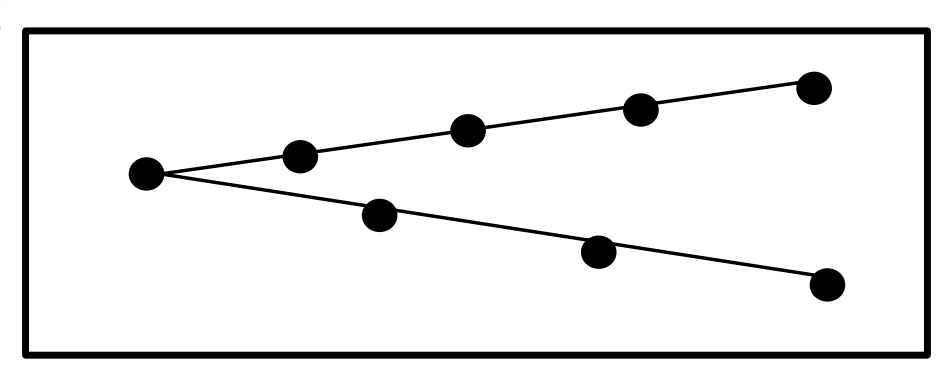




\section{Figure 2 (on next page)}

Non-metric multi-dimensional scaling plots of (a) bacteria; and, (b) fungi grouped according to treatments

Impact of tillage treatment on soil microbial community composition. Plots are non-metric multi-dimensional scaling plots of (a) bacterial; and, (b) fungal community data grouped according to treatments: (triangle-down) Permanent pasture, (square) Permanent fallow, (diamond) Intensive tillage, (triangle-up) Moderate tillage, (circle) No-till. The scaling is based on a Bray-Curtis similarity matrix of ARISA profiles. All data are from soil samples of 0 - 7.5 $\mathrm{cm}$ depth. 2D stress values are 0.21 and 0.23 for bacterial and fungal data, respectively. PERMANOVA revealed significant treatment effects for both bacterial and fungal communities $(p<0.001)$. 


\section{Figure 3 (on next page)}

Non-metric multi-dimensional scaling plots of (a) bacteria; and, (b) fungi grouped according to treatment and sampling depth.

Impact of crop management on microbial community composition measured at different soil depths. Plots are non-metric multi-dimensional scaling plots of (a) bacterial; and, (b) fungal community data grouped according to treatments (triangle-down) Permanent pasture, (square) Permanent fallow, (diamond) Intensive tillage, (triangle-up) Moderate tillage, (circle) No-till. The scaling is based on a Bray-Curtis similarity matrix of ARISA profiles. The trajectory shows the movement of data points related to depth (1) $0-7.5 \mathrm{~cm}$, (2) $7.5-15 \mathrm{~cm}$, (3) 15 $25 \mathrm{~cm}$, (4) $25-30 \mathrm{~cm}$ for average data from each treatment. 2D stress values are 0.09 and 0.16 for bacterial and fungal data, respectively. The significance (PERMANOVA p values) of differences related to treatment ( $T r)$, sample depth (De) and their interaction ( $\operatorname{Tr} \times \mathrm{De})$ are shown on each plot. 


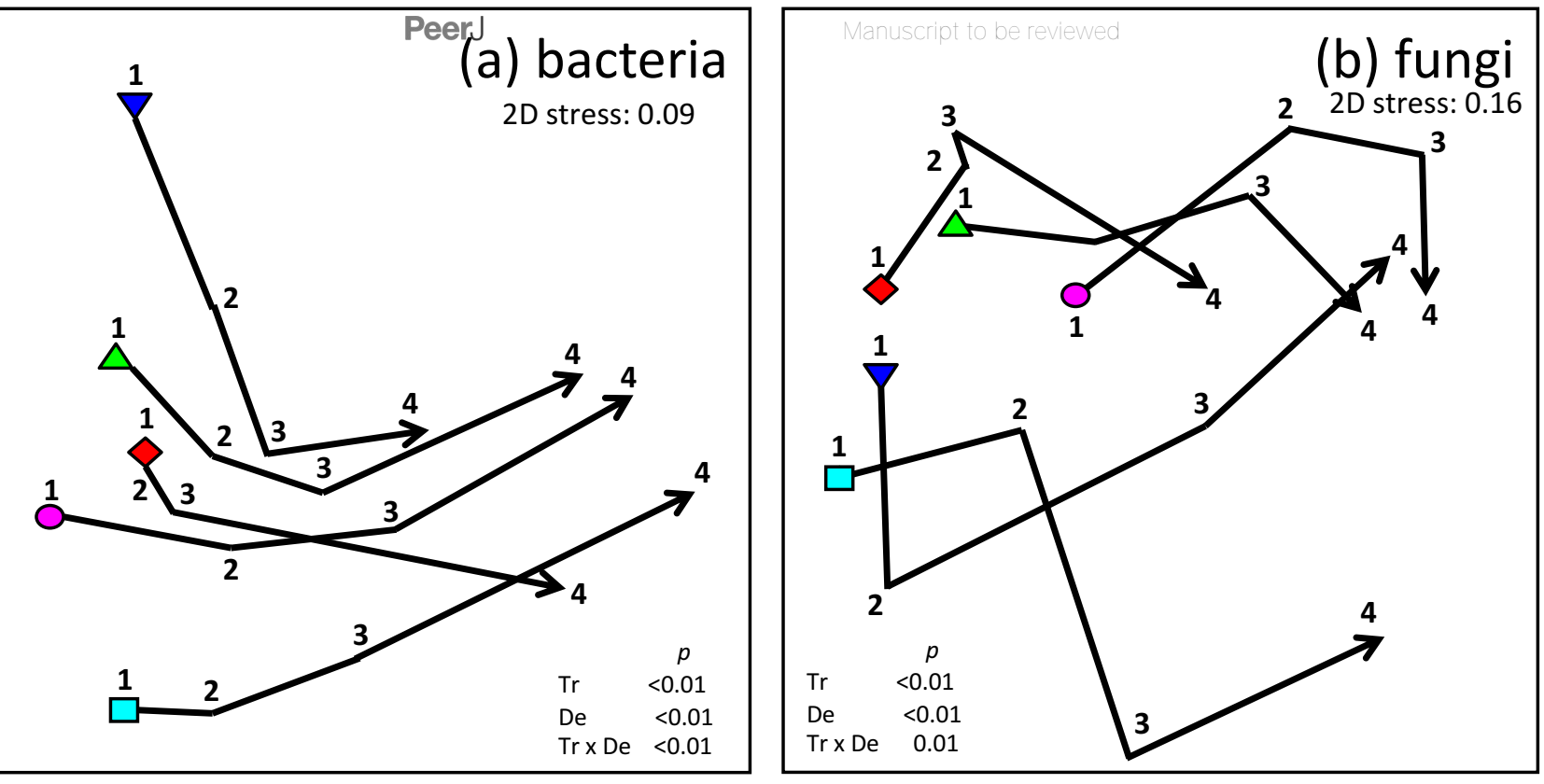

$\boldsymbol{\nabla}$ Permanent pasture, no-till

$\square$ Permanent fallow, no-till

$\diamond$ Cropping, intensive till

$\triangle$ Cropping, moderate till

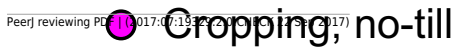




\section{Figure 4 (on next page)}

Taxon richness of (a) bacteria and (b) fungi as a function of soil depth.

Median values are represented by a thick line in each box, and whiskers represent $1.5 \mathrm{x}$ the interquartile range. 



\section{Table $\mathbf{1}$ (on next page)}

Mean values ( \pm S.E.) for soil chemistry variables and significance from two-way ANOVA ( $N=45$ for all comparisons; soil chemistry data were not generated for $25-30 \mathrm{~cm}$ ] samples).

Different letters ( $a, b, c, d)$ indicate significantly different treatment effects using Tukey's Honestly significant difference multiple comparison tests. Treatments are as follows: $\mathrm{Pp}=$ Permanent pasture, $\mathrm{Pf}=$ Permanent fallow, $\mathrm{li}=$ Intensive tillage, $\mathrm{Mm}=$ Moderate tillage, $\mathrm{Nn}$, $=$ No-till. Depths are as follows: $\mathrm{t}=\operatorname{top}(0-7.5 \mathrm{~cm}), \mathrm{m}=$ middle $(7.5-15 \mathrm{~cm})$ and $\mathrm{b}=$ bottom $(15-25 \mathrm{~cm})$. 


\begin{tabular}{|c|c|c|c|c|c|c|c|c|}
\hline Variable & Unit & Mean & \pm S.E. & Treatment $P$ & Depth $P$ & Interaction $P$ & Treatment rank $^{*}$ & Depth rank ${ }^{*}$ \\
\hline Total C & $\mathrm{g} \mathrm{kg}^{-1}$ & 21.9 & \pm 0.09 & $<0.001$ & $<0.001$ & $<0.001$ & ${ }^{\text {a }} \mathrm{Pp}>^{b} \mathrm{Mm}>^{b} \mathrm{Nn}>^{b} \mathrm{Ii}>{ }^{c} \mathrm{Pf}$ & ${ }^{a}>>b m>c b$ \\
\hline Total N & $\mathrm{g} \mathrm{kg}^{-1}$ & 1.90 & \pm 0.01 & $<0.001$ & $<0.001$ & $<0.001$ & ${ }^{\mathrm{a}} \mathrm{Pp}>{ }^{b} \mathrm{Mm}>{ }^{b} \mathrm{Nn}>{ }^{b} \mathrm{Ii}>\mathrm{c} \mathrm{Pf}$ & ${ }^{a} t>b m>c b$ \\
\hline MWD & $\mathrm{mm}$ & 1.30 & \pm 0.09 & $<0.001$ & $<0.001$ & 0.015 & ${ }^{\mathrm{a} P p}>\mathrm{b} \mathrm{Nn}>\mathrm{b} \mathrm{Mm}>\mathrm{c} \mathrm{Ii}>\mathrm{d} \mathrm{Pf}$ & $\mathrm{a}_{\mathrm{t}}>\mathrm{b} \mathrm{m}>\mathrm{c} \mathrm{b}$ \\
\hline $\mathrm{MBC}$ & $\mu \mathrm{g} \mathrm{g}^{-1}$ & 386.91 & \pm 32.9 & $<0.001$ & $<0.001$ & $<0.001$ & ${ }^{\mathrm{a}} \mathrm{Pp}>{ }^{\mathrm{b}} \mathrm{Mm}>{ }^{\mathrm{b}} \mathrm{Ii}>\mathrm{b} \mathrm{Nn}>\mathrm{cPf}$ & $\mathrm{at}^{\mathrm{b}}>\mathrm{b} \mathrm{m}>\mathrm{c} \mathrm{b}$ \\
\hline $\mathrm{MBN}$ & $\mu \mathrm{g} \mathrm{g}^{-1}$ & 59.17 & \pm 4.70 & $<0.001$ & $<0.001$ & $<0.001$ & ${ }^{\mathrm{a}} \mathrm{Pp}>\mathrm{b} \mathrm{Mm}>\mathrm{b} \mathrm{Ii}>{ }^{\mathrm{b}} \mathrm{Nn}>\mathrm{cPf}$ & $\mathrm{a}_{\mathrm{t}}>\mathrm{b} \mathrm{m}>\mathrm{c} \mathrm{b}$ \\
\hline $\mathrm{pH}$ & & 5.43 & \pm 0.06 & $<0.001$ & $<0.001$ & 0.003 & ${ }^{\mathrm{a} P p}>\mathrm{b} \mathrm{Mm}>\mathrm{b} \mathrm{Nn}>\mathrm{b} \mathrm{Ii}>\mathrm{cPf}$ & ${ }^{a} m>a t>b b$ \\
\hline Moisture & $\%$ & 21.03 & \pm 0.44 & $<0.001$ & $<0.001$ & $<0.001$ & ${ }^{\mathrm{a}} \mathrm{Nn}>{ }^{\mathrm{a}} \mathrm{Ii}>\mathrm{a} \mathrm{Mm}>\mathrm{a} \mathrm{Pf}>\mathrm{b} \mathrm{Pp}$ & $\mathrm{at}^{\mathrm{a}}>\mathrm{b} \mathrm{m}>\mathrm{c} \mathrm{b}$ \\
\hline Exch. acid & $\mathrm{cmol}_{\mathrm{c}} \mathrm{kg}^{-1}$ & 0.53 & \pm 0.05 & $<0.001$ & 0.822 & 0.217 & ${ }^{\mathrm{a} P f}>{ }^{\mathrm{bc}} \mathrm{Ii}>{ }^{\mathrm{bc}} \mathrm{Nn}>{ }^{\mathrm{bc}} \mathrm{Mm}>\mathrm{c} \mathrm{Pp}$ & $\mathrm{a} b>\mathrm{a} m>\mathrm{at}$ \\
\hline Exch. al & $\mathrm{cmol}_{\mathrm{c}} \mathrm{kg}^{-1}$ & 0.34 & \pm 0.04 & $<0.001$ & 0.267 & 0.178 & ${ }^{\mathrm{a}} \mathrm{Pf}>{ }^{\mathrm{bc}} \mathrm{Ii}>{ }^{\mathrm{bc}} \mathrm{Nn}>{ }^{\mathrm{bc}} \mathrm{Mm}>\mathrm{c} \mathrm{Pp}$ & ${ }^{a} b>{ }^{a} m>a t$ \\
\hline
\end{tabular}

1

2 *Means for each level of treatment and depth were ranked from highest to lowest

3 